\title{
Genomic breeding
}

\section{GENOME-WIDE ASSOCIATION STUDY FOR MILK PRODUCTION AND REPRODUCTION TRAITS IN RUSSIAN HOLSTEIN CATTLE POPULATION}

\section{A.A. SERMYAGIN ${ }^{1}$, E.A. GLADYR' ${ }^{1}$, S.N. KHARITONOV ${ }^{1}$, A.N. ERMILOV ${ }^{1}$, N.I. STREKOZOV ${ }^{1}$, G. BREM ${ }^{1,2}$, N.A. ZINOVIEVA ${ }^{1}$}

${ }^{1}$ L.K. Ernst All-Russian Research Institute of Animal Husbandry, Federal Agency of Scientific Organizations, pos. Dubrovitsy, Podolsk Region, Moscow Province, 142132 Russia, e-mail alex_sermyagin85@mail.ru

${ }^{2}$ Institute of Animal breeding and Genetics, University of Veterinary Medicine, Veterinärplatz, A-1210, Vienna, Austria

Acknowledgements:

Supported by the Russian Ministry of Education and Science, project number RFMEFI60414X0062.

Received September 7, 2015

\section{Abstract}

Genome-wide association study (GWAS) has been proven as a powerful tool for identifying genomic variants associated with economically important traits in domestic animal species. Development of the methods for genomic evaluation opens the new opportunities in improvement of milk production and fertility traits of livestock. The objective of our study was to evaluate the wholegenome associations between single nucleotide polymorphisms (SNPs) and estimated breeding values (EBVs) for milk production and reproduction traits in Russian Holsteins. SNPs screening was performed in 195 progeny-tested and 61 young bulls using Illumina Bovine SNP50 v2 BeadChip. EBVs were calculated for milk production traits (305-d milk yield (MY), milk fat content (FC), milk protein content (PC), milk fat yield (FY) and milk protein yield (PY)) and reproduction performances (age at fist calving (CA), calving difficulty (CD), conception rate (CR), days open (DO), gestation length (GL) and interval between calving (CI)) using BLUP Sire Model approach. In total, 41370 SNPs were selected for the association analysis based on the quality control results. Direct genomic values (DGV) were calculated by GBLUP approach using genomic relationship matrix (G). Genomic EBVs (GEBVs) were calculated as combination of residual polygenic effects (EBV) with the DGV. To increase the probabilities of GWAS values we used the GEBV values for young bulls, whereas deregressed DGV values were used for progeny-tested bulls. The Bonferroni correction test for detection of significant associations and local false discovery rate (LocFdr) were used to check a type I errors in null-cases hypothesis. Heritability coefficient values for reproduction traits ranged from 0.035 for $\mathrm{CR}$ to $0.221 \mathrm{CA}$, whereas for milk production traits they were higher, i.e. from 0.250 for MY to 0.401 for PC. According to the Bonferroni and LocFdr tests, we have identified several high-significant SNPs, which were associated both with milk production and with fertility traits. Two SNPs with the most significant effect on MY were located on BTA17 (ARS-BFGLNGS-50172) and BTA13 (Hapmap54246-rs29017970). The association analysis for milk components revealed four SNPs at conservative regions, which were significantly associated with FC, i.e. BTA-104917-no-rs and BTB-01604502 (58 Mb, BTA9), ARS-BFGL-NGS-107379 and ARS-BFGL-NGS-4939 (1.8-2.0 Mb, BTA14), and one SNP, which was significantly associated with PC - Hapmap 43278-BTA-50082 (BTA20). Polymorphisms $A R S-B F G L-B A C-7205$ (BTA1) and Hapmap48395-BTA-58382 (BTA5) were associated with PY. Several SNPs were found to be associated with reproduction traits, i.e. $B T B-01622929$ on BTA1 for CA, $A R S-B F G L-N G S$-89711 on BTA27 for CR, $A R S-B F G L-N G S$ 117881 on BTA5 for DO, BTA-31636-no-rs on BTA1 and Hapmap26774-BTA-163037 on BTA27 for CI. The significant effects of SNPs explained up to more than $9.0 \%$ of additive genetic variances. Some of the referent mutations with most significant effect were located within or close to the genes TRAFD1, DGAT1, SLC16A7, DUSP26 and CCDC58. Thus, application of a genome-wide analysis allows with high accuracy to detect the QTL for medium and low heritable productive and reproductive traits in Russian Holsteins.

Keywords: genome-wide association analysis, heritability, milk production, fertility traits 
grams is performed without identifying the impact of any functional genes. In the last quarter of the century, molecular genetic methods are developed at a faster rate - from identifying particular genes that control individual physiological processes to the quantitative trait loci (QTL) and single nucleotide polymorphism (SNP) which mark a set of productive qualities in animals [1-3]. Magnitude of the effect of a single gene responsible for the quantitative and qualitative traits in an animal or in blood groups has a low proportion of genetic variation that contributes to the phenotypic expression of the trait $[4,5]$. Therefore, animal selection does not guarantee the precise inheritance of productive values in generations. Application of short tandem repeats (STR), the microsatellites, does not provide the desired QTL mapping effect as well, as even in the possible presence of siblings and half-siblings in animal groups, QTL and STR chromosome linkage analysis is performed in the interval of $20 \mathrm{cM}$ or greater, which makes it difficult to determine the main mutations [6].

Genome-wide association study (GWAS) is a developed marker-assisted selection (MAS) method, when genetic markers used are distributed through the genome in such a way that all QTLs are in linkage disequilibrium (LD) for at least with one of them. MAS studies are focused on precise mapping of certain QTLs provided that the gene belonging to QTL may be identified. In turn, GWAS effectiveness depends on the number of SNPs. If SNPs are located too far apart on the chromosome, then a QTL can not be in sufficient linkage disequilibrium with at least one of the markers and, therefore, the locus would not be found. An increase in the density of SNP genome covering improves the probability of QTL determination and, largely, the mapping precision [7, 8].

Thus, significant associations with economically important traits have been found in cattle breeds using 10,000 SNPs, but according to M.E. Goddard [6], 300,000 SNPs are required for interbreed analysis in Bos taurus. The number of SNPs of about 50,000 may be quite enough for a single breed, such as Holstein, however the preference is given to the samples of several breeds and high density SNP panels for more precise mapping of QTL and improved reliability of genomic evaluations [9-11].

The number of animals required to study the associations depends on the degree of the effects which is reflected in the proportion of trait variation disclosed by point mutations. This parameter combines the allele frequency and the average difference between SNP genotypes for a quantitative trait. In practice, some SNPs constitute over $4 \%$ of the genetic variance and above, which is a sufficient prediction value in a small sample size even for low inheritable traits [12-14].

GWAS provides an efficient search for relevant polymorphisms both among livestock breeds and within various populations of Holstein origin [1517]. In addition, mapping of economically important traits is performed for the bull and breeding stocks, which is primarily associated with the search for reliable associations for milk fat and protein production [18, 19].

Conservative cattle genome regions with significant associations with milk production traits have been defined: casein cluster $(C S N)$, diacylglycerol O-acyltransferase $(D G A T 1)$, growth hormone receptor $(G H R)$ and others, as well as a number of not previously described population-wide mutations [20-22]. Studies of associations for low inheritable traits make it possible to improve breeding effectiveness by detection or elimination of genes responsible for the health and reproduction of animals, and to fix valuable genotypes in the population [23-27]. The research to find the loci responsible for qualitative animal traits is also of interest [28].

Is necessary to note that the assessment of each marker effects in the 
prediction of genomic breeding value or in associative analysis is performed concurrently with other markers. Every mutation carries a certain proportion of the component of genetic variation, while it is assumed that, under the effects of a plurality of SNPs, the total effect should be low on the average. However, this fact does not prevent a clear picture of associations for the parameters studied [29-32].

The search and study of associations with economically important traits for point genetic mutations in Holstein dairy cattle population have not been performed in Russia earlier. Performing GWAS analysis, we combined the samples for the previously proven and young dairy bulls to confirm the effectiveness and the possibility of using models to predict genomic breeding values for dairy Holstein cattle breeding. These first results of genome-wide analysis will be the basis for the mapping of quantitative trait loci responsible for the formation of productive and reproductive qualities of animals.

The purpose of this study was to evaluate the whole-genome associations between single nucleotides and estimated breeding values for milk production and reproduction traits in Holstein bulls.

Technique. Collecting and analyzing information on the economically important traits of Holstein bull daughters was performed based on breeding databases in 77 farms in the Moscow region (primary databases were provided by the Regional Information and Breeding center Mospleminform). Using Bovine SNP50 v2 BeadChip (Illumina Inc., CШA) with a density of 54,609 SNPs, we genotyped 256 bulls owned by JSC Head Center for Reproduction of Farm Animals (Bykovo, Moscow Province) and OJSC Moskovskoe Breeding Farm (Noginsk, Moscow Province). The sample included 195 progeny-tested bulls ( $n=47998)$ with an average count of 246 daughter first heifers per bull, and 61 young bulls valued by ancestry (Parent Average, PA). The following phenotypic traits were studied in bull daughters: 305-day milk yield (MY), milk fat content (FC), milk protein content (PC), milk fat yield (FY), and milk protein yield (PY), first calving age (CA), calving easy (CE), conception rate (CR), days open (DO), gestation length (GL), and calving interval (CI).

Bull estimated breeding value (EBV) was calculated using BLUP Sire Model approach, after which the resulting estimates were deregressed, i.e. these were adjusted for the impact of systematic environmental effects (drpEBV) [33].

The equation of mixed type models for estimating bull breeding value was implemented in the SAS IML statistical programming language package (SAS University Edition) [34]:

$$
\mathrm{y}_{\mathrm{ijk}}=\mu+\mathrm{HYS}_{\mathrm{i}}+\mathrm{b}_{1} \mathrm{~A}_{\mathrm{k}}+\mathrm{b}_{2} \mathrm{DO}_{\mathrm{k}}+\text { sire }_{\mathrm{j}}+\mathrm{e}_{\mathrm{ijk}},
$$

where $\mathrm{y}_{\mathrm{ijk}}$ is the $k$-th first heifer trait index; $\mu$ is population constant; $\mathrm{HYS}_{\mathrm{i}}$ is fixed effect of the $i$-th «herd-year-season» calving; $b_{1}$ and $b_{2}$ are linear regression coefficients; $\mathrm{A}_{\mathrm{k}}$ is first calving age of the $k$-th heifer; $\mathrm{DO}_{\mathrm{k}}$ is days open of the $k$-th first heifer; sire ${ }_{j}$ is randomized effect of the $j$-th bull with normal distribution with a mean of 0 and a variance of $A \sigma_{\mathrm{a}}{ }^{2}$, where $\mathrm{A}$ is additive relationship matrix; $\mathrm{e}_{\mathrm{ijk}}$ is unaccounted factor effect.

Genotyping quality control and regression analysis for associations was performed using Plink v. 1.07 software [35]. The resulting number of SNPs was 41370. Previously, we have found that genomic enhanced breeding value (GEBV) was by $9-45 \%$ greater compared to the estimation on the ancestors [36]. In this regard, GEBV values for both young and progeny-tested bulls were used in the analysis of the associations

Estimation of genomic relationship matrix $(\mathrm{G})$ was performed according to the algorithm developed by P.M. VanRaden (37) in the R programming language environment [38]. The matrix consisted of elements - homozygous and 
heterozygous loci estimations: $A A=1, A B=0, B B=-1$. Heritability coefficients, genetic and paratypic variances were obtained based on two-factor variance hierarchical complex. GEBVs were calculated as combination of SNP marker direct genomic value (DGV) and EBV (PA) according to the GBLOP approach using the following linear model [37]:

$$
\mathrm{DRP}=\mathrm{Xb}+\mathrm{Zu}+\mathrm{e} \text {, }
$$

where DRP is known drpEBV vector of pseudo phenotypic data located on diagonal matrix $\mathrm{W}$, with the weighted effective daughter contribution coefficients: $\mathrm{EDC}=\mathrm{k} \times \mathrm{r}^{2} /\left(1-\mathrm{r}^{2}\right)$ with the variation ratio $\mathrm{k}=\left(4-\mathrm{h}^{2}\right) / \mathrm{h}^{2}$ (here, $\mathrm{r}^{2}$ is a significance of estimation for trait, $\mathrm{h}^{2}$ is the value heritability); $\mathrm{Xb}$ is a matrix containing one common constant in the model; $\mathrm{u}$ is known prediction vector for $\mathrm{DGV}$ ( $\mathrm{G}$ is a genomic relationship matrix), where $\mathrm{Z}$ is a single diagonal matrix.

The system of normal equations is as follows:

$$
\left[\begin{array}{cc}
\mathrm{X}^{\prime} \mathrm{WX} & \mathrm{X}^{\prime} \mathrm{WZ} \\
\mathrm{Z}^{\prime} \mathrm{WX} & \mathrm{Z}^{\prime} \mathrm{WX}+\mathrm{kG}^{-1}
\end{array}\right]\left[\begin{array}{l}
\mathrm{b} \\
\mathrm{u}
\end{array}\right]\left[\begin{array}{l}
\mathrm{X}^{\prime} \mathrm{WDRP} \\
\mathrm{Z}^{\prime} \mathrm{WDRP}
\end{array}\right] \text {. }
$$

To confirm the significant impact of SNP and identify significant regions in cattle genome, a number of tests were used to check for null-cases hypotheses, including the Bonferroni correction test (threshold value of $\mathrm{P}<1.2 \times 10^{-6}$, $0.05 / 41370$ ), the detection of local false discovery rate (LocFdr) (in B. Efron modification) which was estimated by maximum likelihood method implemented in the locfdr package, $\mathrm{R}$ language [39], and the Fdr criterion value according to the Y. Benjamini and Y. Hochberg approach [40] with an empirical estimate threshold value of $\mathrm{P}<0.05$.

To search for the genes closely associated with economic traits, the $\mathrm{Na}$ tional Center for Biotechnology Information (NCBI) database was used. Functional gene identification was performed using the Discover EggNOG 4.1 database (http://eggnogdb.embl.de/\#/app/home). Data visualization was conducted using the qqman package and $\mathrm{R}$ programming language [41].

Results. Heritability coefficient values $\left(\mathrm{h}^{2}\right)$ for milk production and reproduction traits indicated the possibility for various breeding in a dairy cattle population. So, to improve reproductive and fertility traits with low $\mathrm{h}^{2}$ in the range from $0.035 \pm 0.005$ to $0.068 \pm 0.007$, a reduction of generation interval and(or) an increase in the intensity of animal selection are required. At the same time, it is possible to predict a higher breeding response based on milk production traits with moderate heritability (Table 1).

1. Heritability and variability parameters for milk production and reproduction

\begin{tabular}{|c|c|c|c|c|c|c|c|}
\hline Parameter & $\mathrm{h}^{2} \pm \mathrm{m}_{\mathrm{h}}{ }^{2}$ & $\sigma_{\mathrm{P}}$ & $C_{V_{\mathrm{P}}}$ & $\sigma_{\mathrm{A}}$ & $C V_{\mathrm{A}}$ & $\sigma_{U}$ & $\mathrm{CV}_{\mathrm{U}}$ \\
\hline 305-day milk yield, kg & $0.281 \pm 0.014$ & 1317 & 21 & 697 & 11 & 986 & 16 \\
\hline Milk fat content, $\%$ & $0.250 \pm 0.013$ & 0.37 & 9 & 0.19 & 5 & 0.27 & 7 \\
\hline Milk fat, kg & $0.328 \pm 0.015$ & 57.8 & 23 & 33.1 & 13 & 39.6 & 16 \\
\hline Milk protein content, $\%$ & $0.401 \pm 0.016$ & 0.19 & 6 & 0.12 & 4 & 0.13 & 4 \\
\hline Milk protein, $\mathrm{kg}$ & $0.370 \pm 0.016$ & 43.8 & 22 & 26.6 & 13 & 29.6 & 15 \\
\hline First calving age, months & $0.221 \pm 0.012$ & 3.8 & 14 & 1.8 & 6 & 2.9 & 11 \\
\hline Calving easy, score & $0.068 \pm 0.007$ & 1.03 & 242 & 0.27 & 63 & 0.89 & 210 \\
\hline Conception rate, units & $0.035 \pm 0.005$ & 1.27 & 63 & 0.24 & 12 & 1.23 & 61 \\
\hline Days open, days & $0.059 \pm 0.006$ & 86.5 & 56 & 20.9 & 14 & 83.4 & 54 \\
\hline Gestation length, days & $0.036 \pm 0.005$ & 12.7 & 5 & 2.4 & 1 & 12.5 & 5 \\
\hline Calving interval, days & $0.063 \pm 0.007$ & 82.4 & 19 & 20.6 & 5 & 79.2 & 19 \\
\hline
\end{tabular}
traits in Holstein cattle population (Moscow region)

Constancy of FC, PC, CA, GL, and CI traits was typical for the coefficients of genetic variability. Regardless of the nature of economically important qualities inheritance for FY, PY, DO, CR, and CE traits, an increase in the values of coefficient of variation was observed which was associated with a signifi- 
cant proportion of the effects of paratypic factor.
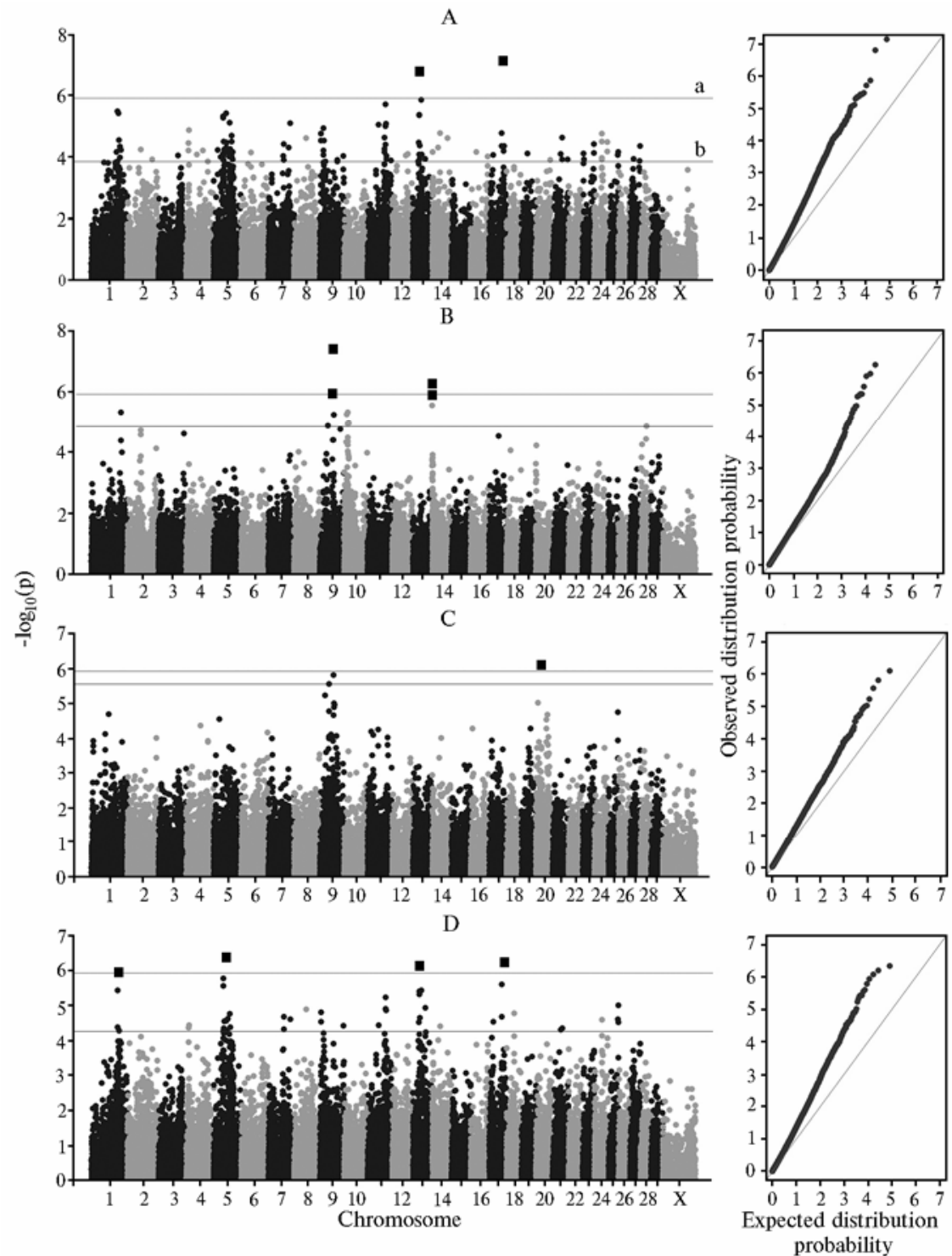

Fig. 1. GWAS results (genome-wide association study, on the left) and relevant probabilities of estimation significance distribution (q-q plot, on the right) for milk yield (A), milk fat content (B), milk protein content $(\mathrm{C})$, milk protein yield (D) in Holstein cattle population (Moscow Province): $\mathrm{a}$ and $\mathrm{b}$ - thresholds according to Bonferroni and Fdr, respectively. Squares signify compliance in significance for the null hypothesis testing according to Bonferroni (highly significant results for associations).

According to the analysis of milk production traits, significant associations with EBV were defined in the bulls. According to Fdr criterion with a theshold value of $\mathrm{P}<0.05,124$ SNPs were defined for MY, while LocFdr and Bonferroni tests identified only 2 SNPs of high significance value $\left(\mathrm{P}<1.2 \times 10^{-6}\right)-$ ARS-BFGL-NGS-50172 (Bos taurus autosome, BTA17) and Hapmap54246rs29017970 (BTA13) (Fig. 1). Conservative loci $\left(\mathrm{P}=1.2 \times 10^{-6}-4.1 \times 10^{-8}\right) B T A$ 104917-no-rs and BTB-01604502 (58 Mb, BTA9), ARS-BFGL-NGS-107379 and $A R S-B F G L-N G S-4939$ (1.8-2.0 Mb, BTA14), Hapmap 43278-BTA-50082 (BTA20) were revealed for FC and PC, with the maximum possible number of significant point mutations, according to Fdr criteria, ranging from 3 to 13 .

No associations were identified for FY, while 48 SNPs mostly located 
on the 5-th and 13-th autosomes were obtained for PY (Fdr, $\mathrm{P}<0.05)$. However, the number of highly significant polymorphisms decreased to 4 , according to Bonferroni and LocFdr criteria: $A R S-B F G L-B A C-7205$ (119 Mb, BTA1), Hapmap48395-BTA-58382 (54 Mb, BTA5), Hapmap54246-rs29017970 (30 $\mathrm{Mb}, \mathrm{BTA13}$ ), and $A R S-B F G L-N G S-50172$ (64 Mb, BTA17). For the last two SNPs, there were typical associations with milk yields per standard lactation, suggesting a close genetic relationship and the efficiency of breeding for milk protein.

2. Significant associations of single nucleotide polymorphisms (SPNs) and estimated breeding values against point mutations and their genomic localization (Holstein cattle population, Moscow Province)

\begin{tabular}{|c|c|c|c|c|c|c|c|c|c|}
\hline SNP & BTA & Position & Allele & \begin{tabular}{|l|} 
Allele \\
frequency, \\
$X \pm m$
\end{tabular} & $\begin{array}{l}\text { Effect, } \\
X \pm m\end{array}$ & $\mathrm{P}$ & $\mathrm{R}^{2}, \%$ & 6 Closest gene & $\begin{array}{l}\text { Genetic } \\
\text { distance, bp }\end{array}$ \\
\hline \multicolumn{10}{|c|}{ 305-d a y milk yie ld, kg } \\
\hline $\begin{array}{l}A R S-B F G L- \\
N G S-50172\end{array}$ & 17 & 64342186 & $C$ & $0.275 \pm 0.020$ & $-132.6 \pm 23.9$ & $7.6 \times 10^{-8}$ & 10.9 & TRAFDI & 10778 \\
\hline $\begin{array}{l}\text { Hapmap54246- } \\
\text { Is } 29017970\end{array}$ & 13 & 30878341 & $G$ & $\begin{array}{l}0.126 \pm 0.015 \\
\text { Milk fat }\end{array}$ & $\begin{array}{r}+172.3 \pm 32.0 \\
\text { c ontent }\end{array}$ & $\begin{array}{l}1.7 \times 10^{-7} \\
\%\end{array}$ & 10.4 & LOC104973750 & Within gene \\
\hline $\begin{array}{l}\text { BTA-104917- } \\
\text { no-IS } \\
A R S-B F G L-\end{array}$ & 9 & 58113021 & $A$ & $0.304 \pm 0.020$ & $+0.036 \pm 0.00$ & $64.1 \times 10^{-8}$ & 11.3 & EPHA7 & 279992 \\
\hline$N G S-107379$ & 14 & 2054457 & $G$ & $0.387 \pm 0.022$ & $+0.030 \pm 0.00$ & $65.9 \times 10^{-7}$ & 9.5 & LOC786966 & 298 \\
\hline $\begin{array}{l}B T B-01604502 \\
A R S-B F G L-\end{array}$ & 9 & 58145538 & $A$ & $0.368 \pm 0.021$ & $+0.033 \pm 0.00$ & $71.1 \times 10^{-6}$ & 9.0 & EPHA7 & 312509 \\
\hline$N G S-4939$ & 14 & 1801116 & $G_{\mathrm{N}}$ & $\begin{array}{r}0.347 \pm 0.021 \\
\text { M ilk prot }\end{array}$ & $\begin{array}{l}+0.029 \pm 0.006 \\
\text { ein cont }\end{array}$ & $\begin{array}{l}61.2 \times 10^{-6} \\
\text { ent } \%\end{array}$ & 8.9 & $D G A T 1$ & Within gene \\
\hline $\begin{array}{l}\text { Hapmap43278- } \\
\text { BTA-50082 }\end{array}$ & 20 & 25185940 & $A$ & $\begin{array}{r}0.053 \pm 0.010 \\
\text { Prot e i }\end{array}$ & $\begin{array}{l}+0.033 \pm 0.00 \\
\text { n y i e } 1 d\end{array}$ & $\begin{array}{l}78.0 \times 10^{-7} \\
\mathrm{~kg}\end{array}$ & 9.3 & $A R L 15$ & Within gene \\
\hline Hapmap48395- & & & & & & & & & \\
\hline $\begin{array}{l}B T A-58382 \\
A R S-B F G L-\end{array}$ & 5 & 54120342 & $G$ & $0.382 \pm 0.022$ & $-3.7 \pm 0.7$ & $4.6 \times 10^{-7}$ & 9.7 & SLC16A7 & Within gene \\
\hline $\begin{array}{l}\text { NGS-50172 } \\
\text { Hapmap } 54246-\end{array}$ & 17 & 64342186 & $P D$ & $0.275 \pm 0.020$ & $-3.9 \pm 0.8$ & $6.4 \times 10^{-7}$ & 9.5 & TRAFDI & 10778 \\
\hline $\begin{array}{l}\text { Is } 29017970 \\
A R S-B F G L-\end{array}$ & 13 & 30878341 & $G$ & $0.127 \pm 0.015$ & $+5.1 \pm 1.0$ & $8.4 \times 10^{-7}$ & 9.3 & LOC104973750 & Within gene \\
\hline$B A C-7205$ & 1 & 119976661 & ${ }_{\mathrm{F}}$ & $\begin{array}{r}0.416 \pm 0.022 \\
\text { irst calv }\end{array}$ & $\begin{array}{l}+3.5 \pm 0.7 \\
\text { ing age }\end{array}$ & $\begin{array}{l}1.2 \times 10^{-6} \\
\text { months }\end{array}$ & 9.1 & HPS3 & Within gene \\
\hline ВТВ-01622929 & 1 & 117345968 & $A$ & $\begin{array}{l}0.445 \pm 0.022 \\
\text { Concept }\end{array}$ & $\begin{array}{l}-0.49 \pm 0.09 \\
\text { on rate, }\end{array}$ & $\begin{array}{l}3.7 \times 10^{-7} \\
\text { units }\end{array}$ & 9.8 & LOC104970999 & 56 \\
\hline $\begin{array}{l}A R S-B F G L- \\
N G S-89711\end{array}$ & 27 & 29231663 & $G$ & $\begin{array}{c}0.376 \pm 0.022 \\
\text { D a y s }\end{array}$ & $\begin{array}{l}+0.041 \pm 0.00 \\
\text { o p e n, day }\end{array}$ & $\begin{array}{l}82.1 \times 10^{-7} \\
y s\end{array}$ & 10.2 & DUSP26 & 261502 \\
\hline $\begin{array}{l}A R S-B F G L- \\
N G S-117881\end{array}$ & 5 & 82631679 & $A$ & $\begin{array}{l}0.302 \pm 0.020 \\
\text { Calving }\end{array}$ & $\begin{array}{r}+2.1 \pm 0.4 \\
\text { interval, }\end{array}$ & $\begin{array}{l}1.7 \times 10^{-7} \\
\text { days }\end{array}$ & 10.4 & PPFIBPI & Within gene \\
\hline $\begin{array}{l}\text { Hартар26774- } \\
\text { BTA-163037 } \\
\text { BTA-31636-no- }\end{array}$ & 27 & 42578430 & $A$ & $0.136 \pm 0.015$ & $+0.7 \pm 0.1$ & $1.1 \times 10^{-6}$ & 9.0 & LOC101905415 & 6930 \\
\hline IS & 1 & 67399528 & $P D$ & $\begin{array}{c}0.380 \pm 0.022 \\
\text { Gestatio }\end{array}$ & $\begin{array}{c}-0.5 \pm 0.1 \\
\text { n e ngth }\end{array}$ & $\begin{array}{l}1.2 \times 10^{-6} \\
\text { days }\end{array}$ & 9.0 & CCDC58 & Within gene \\
\hline $\begin{array}{l}\text { BTA-31636-no- } \\
\text { Is } \\
\text { Note. BTA }\end{array}$ & $-c$ & $\begin{array}{l}67399528 \\
\text { e chromoso }\end{array}$ & $\begin{array}{l}C \\
\mathrm{e}, \mathrm{P}\end{array}$ & $\begin{array}{r}0.380 \pm 0.022 \\
- \text { null-case hy }\end{array}$ & $\begin{array}{l}-0.4 \pm 0.1 \\
\text { pothesis prob }\end{array}$ & $\begin{array}{l}1.3 \times 10^{-6} \\
\text { ability erro }\end{array}$ & $\begin{array}{l}9.0 \\
\mathrm{R}^{2}\end{array}$ & $\begin{array}{l}C C D C 58 \\
- \text { coefficient of }\end{array}$ & $\begin{array}{l}\text { Within gene } \\
\text { determination }\end{array}$ \\
\hline
\end{tabular}

GWAS for reproductive qualities and fertility of bull daughters identified genomic regions with 9 (for GL) to 66 (for DO) SNPs localized, with the $\mathrm{P}<0.05$ value of the expected proportion of false deviation (Fig. 2). Using more powerful null hypothesis assessment criteria made it possible to precisely localizate the mutations for CA (BTB-01622929, $117 \mathrm{Mb}$, BTA1), CR ( $A R S$ $B F G L-N G S-89711,29 \mathrm{Mb}$ BTA27), DO (ARS-BFGL-NGS-117881, $82 \mathrm{Mb}$, BTA5) и CI (BTA-31636-no-rs, 67 Mb, BTA1; Hapmap26774-BTA-163037, 42 $\mathrm{Mb}$, BTA27). A significant nucleotide substitution (BTA-31636-no-rs) was identified for GL trait, which was similar to the one found for CI. We could not de- 
tect any significant associations for CE trait which, in our opinion, is due to a high impact of paratypic factors on the trait.

Significance of association estimations for economically important traits was close to normal distribution and had a slight deviation from the theoretically expected distribution, as shown in the quantile-quantile plots (q-q plot, Fig. 1, 2).
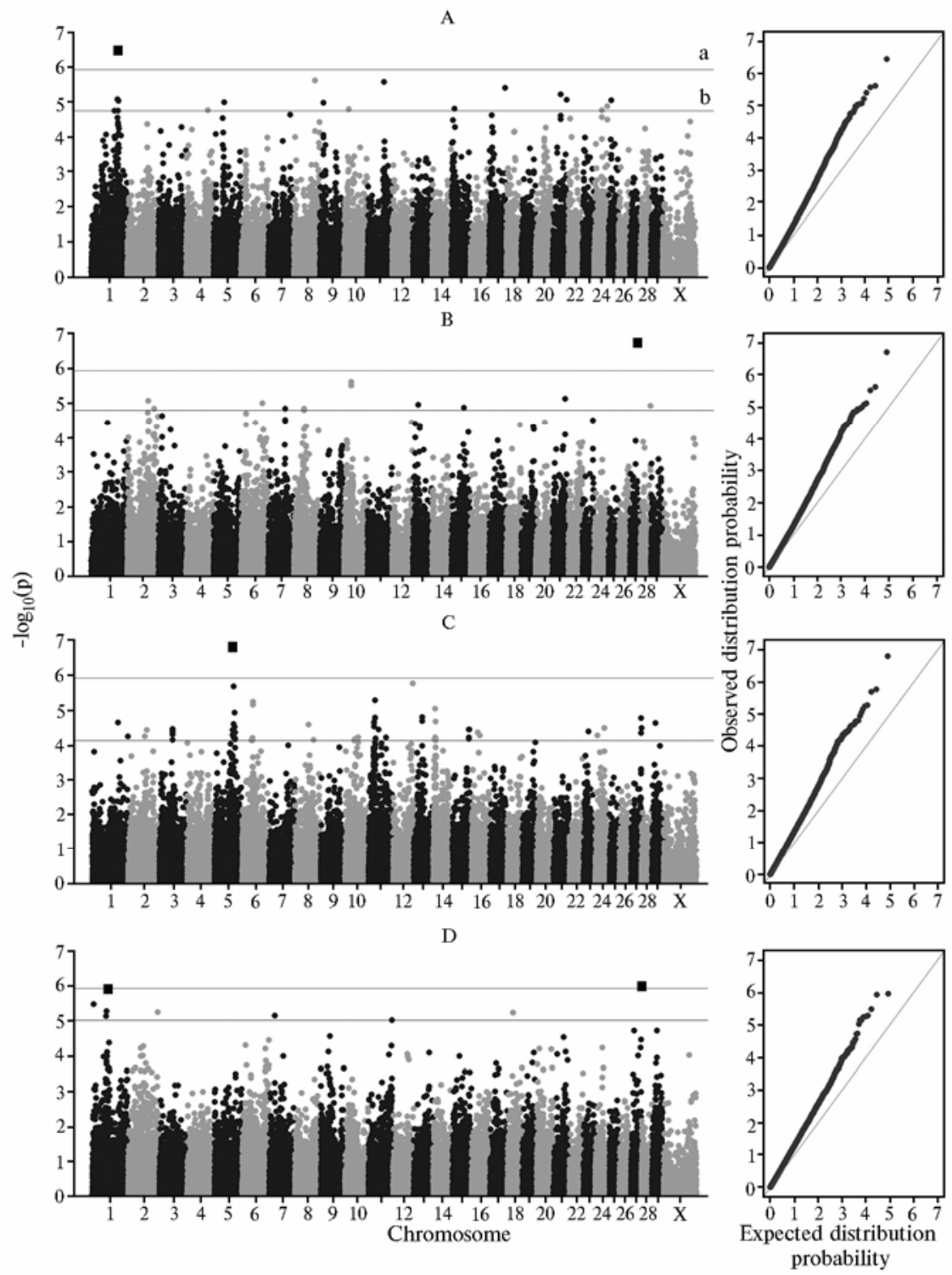

Fig. 2. GWAS results (genome-wide association study, on the left) and relevant probabilities of estimation significance distribution (q-q plot, on the right) for first calving age (A), conception rate (B), days open (C), and calving interval (D) in Holstein cattle population (Moscow region): a and $\mathrm{b}$ - thresholds according to Bonferroni and Fdr, respectively. Squares signify compliance in significance for the null hypothesis testing according to Bonferroni (highly significant results for associations).

Significant single nucleotide polymorphisms were identified both within individual genes and in the closest regions. The additive proportion of each marker effect ranged from 8.9 to $11.3 \%$ of the total trait variability. The marker regression effect figures for the estimation of breeding values were both positive and negative, which indicates the possibility of their use for selecting the best animals and searching and eliminating deleterious mutations. Significance of as- 
sociations ranged from $1.2 \times 10^{-6}$ to $7.6 \times 10^{-8}$. The frequencies of minor alleles for loci were 0.053-0.445 (Table 2).

Analysis of SNPs associated with qualitative trait estimation in Holstein cattle population identified a number of genes involved in various biological processes (Table 2): $T R A F$ is responsible for the immune response, bioregulation, and protein synthesis; EPHA7 controls cell signaling mechanism and regulation of metabolic processes; LOC786966 is associated with cytoskeleton and protein structures of epithelial cells; DGAT1 controls lipid transport and their metabolism; $A R L 15$ is responsible for intracellular metabolism, secretion, and vesicular apparatus; SLC16A7 affects metabolism and carbohydrate transport; HPS3 is associated with cellular processes and pigmentation; DUSP26 is responsible for protective mechanisms at the molecular level and for metabolism of phosphate containing compounds; CCDC58 controls cell cycle, cell division, and the phase of meiosis associated with chromosome division. Three genes (LOC786966, DGAT1, SLC16A7) of the above ones were reference for Holstein cattle, as shown in similar studies performed by J.B. Cole [20] in the North American animal population. Generally, it is noteworthy that associations for most traits may be correlated, being a part of the overall relationship of biological processes in the animal body.

Thus, we have obtained data on the mapping of quantitative trait loci (milk production and reproduction) in Holstein cattle. Highly significant associations for 14 SNPs have been defined in chromosomes 1, 5, 9, 13, 14, 17, 20, and 27 with the additive effect of more than $9 \%$ for a number of parameters. Genes TRAFD1, LOC786966, DGAT1, SLC16A7, DUSP26, and CCDC58 were most conservative in the genome for reference mutations. Genome-wide studies performed for the traits with different heritability make it possible to quite precisely define the associations for genetic mutations. Using the null hypothesis assessment criterion for the expected proportion of false deviations in accordance with the maximum likelihood function allows to expand detection by SNPs. Bonferroni test has a higher capacity of statistical hypothesis testing.

\section{REFEREN C ES}

1. Marzanov N.S., Devrishov D.A., Marzanova S.N., Komkova E.A., Oze rov M.Yu., Kanta n e n Yu. Geneticheskoe markirovanie, sokhranenie raznoobraziya i problemy razvedeniya zhivotnykh [Genetic labeling, conservation of biodiversity and the problems in animals breeding]. Sel'skokhozyaistvennaya Biologiya [Agricultural Biology], 2011, 2: 3-14 (in Russ.).

2. St ol povski i Yu.A. Kontseptsiya i printsipy geneticheskogo monitoringa dlya sokhraneniya in situ porod domestitsirovannykh zhivotnykh Kavkaza [Concept and principles of genetic monitoring for the purpose of preservation in situ of domestical animals kinds]. Sel'skokhozyaistvennaya Biologiya [Agricultural Biology], 2010, 6: 3-8 (in Russ.).

3. Zinov'eva N.A., Strekozov N.I., Yanchukov I.N., Ermilov A.N., Es k i n G.V. Zhivotnovodstvo Rossii, 2015, 3: 27-29 (in Russ.).

4. K u z n e t s o v V.M. Problemy biologii produktivnykh zhivotnykh, 2012, 4: 18-57 (in Russ.).

5. S e r m y a g in A.A., S e $1 \mathrm{t}$ s ov V.I., Kost yu n in a O.V., G la d y r E.A., K h a r z i no v a V.R., Z i n o vi e va N.A. Book of Abstract "International scientific genetic conference «XXVI. GENETIC DAYS». Prague, Czech Republic, 2014: 135-138.

6. G o d d a rd M.E., H a y s B.J. Mapping genes for complex traits in domestic animals and their use in breeding programmes. Nature Reviews Genetics, 2009, 10: 381-391 (doi: 10.1038/nrg2575).

7. W e 11 e r J.I. Quantitative trait loci analysis in animals. $2^{\text {nd }}$ ed. CABI, UK, 2009.

8. Hayes B.J., B ow man P.J., Chamberlain A.J., Goddard M.E. Invited review: Genomic selection in dairy cattle: Progress and challenges. J. Dairy Sci., 2009, 92: 433-443 (doi: 10.3168/jds.2008-1646).

9. Pryce J.E., Gredler B., Bolormaa S., Bowman P.J., Egger-Danner C., Fuerst C., Emmerling R., Sölkner J., Goddard M.E., H a y s B.J. Short communication: Genomic selection using a multi-breed, across-country reference population. $J$. 
Dairy Sci., 2011, 94: 2625-2630 (doi: 10.3168/jds.2010-3719).

10. Pérez O'Brien A.M., U tsunomiya Y.T., Mészáros G., Bickhart D.M., Li u G.E., V a n T a s s e 11 C.P., T a d S., S o n stegard T.S., d a S ilva M.V.B., G a r c i a J.F., S ö 1 kn e r J. Assessing signatures of selection through variation in linkage disequilibrium between taurine and indicine cattle. Genetics Selection Evolution, 2014, 46: 19 (doi: 10.1186/1297-9686-46-19).

11. B o is on S.A., S a n t o s D.J.A., U t s unomiya A.H.T., C a rvalhe i ro R., Neve s H.H.R., P e rez O'B rien A.M., Garcia J.F., Sölkner J., d a S ilva M.V.G.B. Strategies for single nucleotide polymorphism (SNP) genotyping to enhance genotype imputation in Gyr (Bos indicus) dairy cattle: Comparison of commercially available SNP chips. $J$. Dairy Sci., 2015, 98: 4969-4989 (doi: 10.3168/jds.2014-9213).

12. Pryce J.E., Bolorma S., Chamberlain A.J., Bow man P.J., Savin K., God d a rd M.E., H a y e s B.J. A validated genome-wide association study in 2 dairy cattle breeds for milk production and fertility traits using variable length haplotypes. J. Dairy Sci., 2010, 93: 3331-3345 (doi: 10.3168/jds.2009-2893).

13. B olorma a S., Pry c e J.E., Ha y e s B.J., G odd ard M.E. Multivariate analysis of a genome-wide association study in dairy cattle. J. Dairy Sci., 2010, 93: 3818-3833 (doi: 10.3168/jds.2009-2980).

14. Chamberlain A.J., Hayes B.J., Savin K., Bolormaa S., McPartlan H.C., B ow ma n P.J., Van D e r J agt C., M a E a c hern S., Goddard M.E. Validation of single nucleotide polymorphisms associated with milk production traits in dairy cattle. J. Dairy Sci., 2012, 95: 864-875 (doi: 10.3168/jds.2010-3786).

15. Q a nbari S., Pimentel E.C.G., Tetens J., Thaller G., Lichtner P., Sharifi A.R., S i miane r H. A genome-wide scan for signatures of recent selection in Holstein cattle. Animal Genetics, 2010, 41(4): 377-389 (doi: 10.1111/j.1365-2052.2009.02016.x).

16. Maxa J., Neuditschko M., Russ I., Förster M., Medugorac I. Genome-wide association mapping of milk production traits in Braunvieh cattle. J. Dairy Sci., 2012, 95: 53575364 (doi: 10.3168/jds.2011-4673).

17. Fang M., Fu W., Jiang D., Zhang Q., Sun D., Ding X., Liu J. A multiple-SNP approach for genome-wide association study of milk production traits in Chinese Holstein cattle. PLoS ONE, 2014, 9(8): e99544 (doi: 10.1371/journal.pone.0099544).

18. S chopen G.C.B., Visker M.H.P.W., Koks P.D., Mulla art E., van Arendo n k J.A.M., B ove $\mathrm{n} \mathrm{h}$ u is H. Whole-genome association study for milk protein composition in dairy cattle. J. Dairy Sci., 2011, 94: 3148-3158 (doi: 10.3168/jds.2010-4030).

19. Maurice-Van Eijndhoven M.H.T., Bovenhuis H., Veerkamp R.F., Ca$1 \mathrm{u}$ s M.P.L. Overlap in genomic variation associated with milk fat composition in Holstein Friesian and Dutch native dual-purpose breeds. J. Dairy Sci., 2015, 98: 6510-6521 (doi: 10.3168/jds.2014-9196).

20. Cole J.B., Wiggans G.R., Ma L., Sonstegard T.S., Lawlor T.J. Jr., Crooke r B.A., Van Tas se 11 C.P., Yang J., Wang S., Matukumalli L.K., Da Y. Genome-wide association analysis of thirty one production, health, reproduction and body conformation traits in contemporary U.S. Holstein cows. BMC Genomics, 2011, 12: 408 (doi: 10.1186/1471-2164-12-408).

21. Wang X., Wurmser C., Pausch H., Jung S., Reinhardt F., Tetens J., Thalle r G., Fries R. Identification and dissection of four major QTL affecting milk fat content in the German Holstein-Friesian population. PLOS ONE, 2012, 7(7): e40711 (doi: 10.1371/journal.pone.0040711).

22. Cole J.B., Waurich B., Wensch-Dorendorf M., Bickhart D.M., Swal ve H.H. A genome-wide association study of calf birth weight in Holstein cattle using single nucleotide polymorphisms and phenotypes predicted from auxiliary trait. J. Dairy Sci., 2014, 97: 3156-3172 (doi: 10.3168/jds.2013-7409).

23. S a h a n a G., Guldbrandtse n B., Lund M.S. Genome-wide association study for calving traits in Danish and Swedish Holstein cattle. J. Dairy Sci., 2011, 94: 479-486 (doi: 10.3168/jds.2010-3381).

24. Fritz S., Capitan A., D jari A., Rodriguez S.C., B a rbat A., B a u A., Grohs C., We is s., Boussaha M., Esquerre D., Klopp C., Rocha D., B o ichard D. Detection of haplotypes associated with prenatal death in dairy cattle and identification of deleterious mutations in GART, SHBG and SLC37A2. PLOS ONE, 2013, 8(6): e65550 (doi: 10.1371/journal.pone.0065550).

25. Mészáros G., Eaglen S., Wa ld ma n n P., S ö 1 kn e r J. A genome wide association study for longevity in cattle. Open Journal of Genetics, 2014, 4: 46-55 (doi: 10.4236/ojgen.2014.41007).

26. Sahana G., Guldbrandtsen B., Thomsen B., Holm L-E., Panitz F., $\mathrm{B}$ røndum R.F., B e ndixen C., Lund M.S. Genome-wide association study using highdensity single nucleotide polymorphism arrays and whole-genome sequences for clinical mastitis traits in dairy cattle. J. Dairy Sci., 2014, 97: 7258-7275 (doi: 10.3168/jds.2014-8141).

27. Suchocki T., Szyda J. Genome-wide association study for semen production traits in 
Holstein-Friesian bulls. J. Dairy Sci., 2015, 98: 5774-5780 (doi: 10.3168/jds.2014-8951).

28. Mészáros G., Petautschnig E., Schwarzenbacher H., Sölkner, J. Genomic regions influencing coat color saturation and facial markings in Fleckvieh cattle. Animal Genetics, 2015, 46(1): 65-68 (doi: 10.1111/age.12249).

29. Misztal I., Legarra A., Aguilar I. Computing procedures for genetic evaluation including phenotypic, full pedigree, and genomic information. J. Dairy Sci., 2009, 92: 4648-4655 (doi: 10.3168/jds.2009-2064).

30. Aguilar I., M isztal I., Johnson D.L., Legarra A., Tsuruta S., Lawlor T.J. Hot topic: A unified approach to utilize phenotypic, full pedigree, and genomic information for genetic evaluation of Holstein final score. J. Dairy Sci., 2010, 93: 743-752 (doi: 10.3168/jds.2009-2730).

31. Legarra A., D u c ro c q V. Computational strategies for national integration of phenotypic, genomic, and pedigree data in a single-step best linear unbiased prediction. J. Dairy Sci., 2012, 95: 4629-4645 (doi: 10.3168/jds.2011-4982).

32. Přibyl J., Madsen P., Baue r J., Přibylová J., Š i mečková M., Vostrý L., Z avadilová L. Contribution of domestic production records, Interbull estimated breeding values, And single nucleotide polymorphism genetic markers to the single-step genomic evaluation of milk production. J. Dairy Sci., 2013, 96: 1865-1873 (doi: 10.3168/jds.2012-6157).

33. Ga r rick D.J., T a y lor J.F., Ferna ndo R.L. Deregressing estimated breeding values and weighting information for genomic regression analyses. Genetics Selection Evolution, 2009, 41: 55 (doi: 10.1186/1297-9686-41-55).

34. SAS/STAT 9.1 User's Guide. SAS Institute Inc., Cary, NC, 2005.

35. Purcell S., Neale B., Todd-Brown K., Thomas L., Ferreira M., Bender D., Malle r J., Sklar P., d e B a kker P., Daly M.J., Sham P.C. PLINK: a toolset for whole-genome association and population-based linkage analysis. American Journal of Human Genetics, 2007, 81(3): 559-575 (doi: 10.1086/519795).

36. S e r m y a g in A.A., G ladyr' E.A., Kharitonov S.N., Ermilov A.N., Y a n c hu k ov I.N., S tre k o z ov N.I., Z i n ov'e va N.A. Materialy Mezhdunarodnoi nauchnoprakticheskoi konferentsii «Puti prodleniya produktivnoi zhizni korov na osnove optimizatsii razvedeniya, tekhnologii soderzhaniya i kormleniya zhivotnykh» [Proc. Int. Conf. «Optimized rearing and feeding for extended productive life in cows» (in Russ.)]. Dubrovitsy, 2015: 115-120.

37. V a n R a d e n P.M. Efficient methods to compute genomic predictions. J. Dairy Sci., 2008, 91: 4414-4423 (doi: 10.3168/jds.2007-0980).

38. The $R$ Project for Statistical Computing: Free software environment for statistical computing and graphics. Available: http://www.r-project.org [No date].

39. Efron B., Turnbull B.B., $\mathrm{N}$ a rasim an B. Locfdr: Computes local false discovery rates. $R$ package version 1.1-7. 201 Available: http://CRAN.R-project.org/package=locfdr [No date].

40. Benjamini Y., Hochberg Y. Controlling the false discovery rate: a practical and powerful approach to multiple testing. Journal of the Royal Statistical Society, Series B, 1995, 57: 289-300.

41. Tu rne r S.D. qqman: an $R$ package for visualizing $G W A S$ results using $Q-Q$ and Manhattan plots. bioRxiv, 2014. Preprint first posted online May 14, 2014 (doi: 10.1101/005165). 